Article

\title{
Infrastructure Public-Private Partnership (PPP) Investment and Government Fiscal Expenditure on Science and Technology from the Perspective of Sustainability
}

\author{
Chang Liu
}

Citation: Liu, C. Infrastructure Public-Private Partnership (PPP) Investment and Government Fiscal Expenditure on Science and Technology from the Perspective of Sustainability. Sustainability 2021, 13, 6193. https://doi.org/10.3390/ su13116193

Academic Editor: Elżbieta Macioszek

Received: 13 April 2021

Accepted: 27 May 2021

Published: 31 May 2021

Publisher's Note: MDPI stays neutral with regard to jurisdictional claims in published maps and institutional affiliations.

Copyright: (C) 2021 by the author. Licensee MDPI, Basel, Switzerland. This article is an open access article distributed under the terms and conditions of the Creative Commons Attribution (CC BY) license (https:// creativecommons.org/licenses/by/ $4.0 /)$.
School of Economics and Management, Beijing Jiaotong University, Beijing 100044, China; 18113073@bjtu.edu.cn; Tel.: +86-132-6931-5781

\begin{abstract}
In the environment of the continuous development of the Public-Private Partnership (PPP) model, China's "dual circulation" development pattern orientation and "new normal" economic development reform provide the foundation for the development of the PPP model in the field of infrastructure. A good government investment structure and governance environment will help to improve the financial sustainability of infrastructure investment. This paper studies the mechanism of the relationship between fiscal expenditure on science and technology and the development of infrastructure PPP models based on the data of provincial PPP projects in the World Bank database and carries out an empirical analysis. The results show that the positive effect of government fiscal expenditure on science and technology and the development of the infrastructure PPP model in local regions is significant. In addition, intergovernmental competition within the political system of China will have a restraining effect on this relationship. This has certain theoretical and practical significance for the construction and implementation of the mechanism underlying intergovernmental behavior and the infrastructure PPP model.
\end{abstract}

Keywords: fiscal expenditure on science and technology; intergovernmental competition; PPP investment model; infrastructure investment; government governance; economic disparity

\section{Introduction}

In 2020, President Xi proposed "to promote the formation of a new development pattern with domestic and international cycles as the main body, and further accelerate the mutual promotion of the domestic and the international cycle". This view highlights that China's domestic demand has great potential. Due to investment and China's key strategic project overseas, the Belt and Road Initiative (BRI), China has increasingly focused on technology investment in cooperation with the world, especially the EU, to promote win-win cooperation.

Most countries in the world are actively exploring and advancing the reform of the investment and financing system of infrastructure. The practice of various countries has fully proved that this is a historic change in the expansion of investment and financing capacity and the improvement of efficiency. The market-oriented reform of the urban infrastructure investment and financing system is an inevitable trend, and a good system is the basis and prerequisite for shaping sound and rational investment and financing behavior. Transformative system innovation, improvement of technological innovation policies, and growth strategies approaching global social goals can influence and coordinate local and global economic, social and environmental aspects to achieve sustainable development [1].

At the same time, there are still many opportunities for China's development. The adaptability of the supply and demand system is an important starting point for new development concepts. In the context of the "new normal" development of the Chinese economy, China's economic growth tends to grow at a medium-to-high speed, and the mode of economic development is gradually changing. In order to maintain regional economic 
growth and meet the needs of new urbanization development, various regions have been vigorously increasing their infrastructure construction. According to the characteristics of infrastructure construction, construction and operation require a large amount of capital investment, and it is difficult to recover costs. Under the circumstances of increasing financial pressure, local governments cannot afford the entire process of public construction needs, so they seek help from social capital. Therefore, the PPP (Public-Private Partnership) model, because of its advantages in terms of connecting government and private capital, attracting social capital and sharing the government's financial pressure, has gradually developed in China and received national policy support. As of the end of January 2020, there were 12,362 projects (17,632.7 billion yuan) in the PPP database of the Ministry of Finance, with a landing rate of $65.4 \%$, which is higher than those of previous years, but still a very slow increase. What factors affect the process of the local regional development of the PPP model? What is the reason for the slow increase in the implementation rate of the PPP model? Is there any influence path between governments that can promote the development and the success rate of the PPP model? These questions are the starting points of this article.

\subsection{The Introduction of Public-Private Partnership Investment}

The PPP model refers to a public-private partnership and an institutional arrangement of mutual cooperation established by the private sector and the public sector for the purpose of providing public products or services and maximizing their respective advantages. The private sector pursues more economic benefits because they are a long-term public product or service provider; the government and the private sector sign a contract for cooperation between the two parties and are mainly responsible for managing the overall process of the project and supervising the performance of the project's implementation level. Considering their respective interests, both parties set up a project team, make mutual commitments and sign an agreement to clarify the partnership. Therefore, the characteristics of PPP mainly include the diversified profits of participants, franchise period, shared profits and shared risks, special economic characteristics, etc.

The PPP model can allow private knowledge and financial resources to be used to build public infrastructure and share and transfer risks [2]. There is a game relationship between various stakeholders, and through mutual restriction, parties can also promote each other, meaning that the entire project can develop healthily and rapidly and improve resource efficiency [3,4]. A digital platform connects the various stakeholders in the PPP project and can balance the satisfaction and sustainability of all parties [5]. Using project financing can alleviate agency problems, reduce information asymmetry costs and improve risk management to create value, thereby reducing capital costs.

Increasing numbers of scholars are beginning to pay attention to investment in the field of basic implementation. They have also highlighted that the incompleteness of infrastructure is an important factor hindering the sustainable development of a country's economy [6]. The PPP model is an active attempt by the Chinese government to reform the public utility investment and financing system. The basic idea is to use market mechanism principles to raise funds for the development of public utilities, diversify investment entities and improve the management of public utilities. The PPP model is widely used in the field of infrastructure, and a large amount of research on the PPP model is also limited to the field of infrastructure, meaning that the PPP model mentioned in this article is based on the PPP model in the field of infrastructure. A PPP project is a complex system with several stakeholders. The Green Belt and Road Initiative PPP project entails multinational cooperation; therefore, the risks associated with this project are complex and varied [7]. However, in the process of the development of the PPP model, there are some unsuccessful cases that cause scholars all over the world to focus on the effective factors that lead to the failure of PPP projects. From the internal perspective of the PPP model, factors such as the risk structure, investment composition and construction period of a construction project may affect its effectiveness [8-11]. Additionally, from the analysis of 
the external environment, national and regional political and economic system policies, regional economic development conditions, financing channels, etc. are also influential factors [12,13]. Under the institutional environment specific to China, the process of marketization and the level of fiscal decentralization between regional governments will also affect the development level of the regional PPP model $[14,15]$. The party structure and equity allocation in the PPP model can affect the financing plan and development of a project [16]. Existing research mostly starts from a macroeconomic perspective; thus, there are still gaps in the research into the internal logic mechanism and deeper influencing factors between government and private capital.

\subsection{Regional Economic Background}

Governments and policymakers should reinforce policies for the reduction of environmental pollution and green financing policies, and they should encourage aspiring environmental entrepreneurs to set up environmentally driven businesses, promote the use of environmental products to mitigate environmental problems and achieve sustainable development [17]. The economic growth of a country and a region has a close relationship with domestic and regional technological progress. An innovative system is a network system with coordinated development among various entities [18]. The fiscal expenditure by the government on science and technology is an important policy tool to adjust the industrial structure and optimize the allocation of resources. It emphasizes the allocation of output targets and leads to industrial development [19]. In China's unique political "promotion championship" environment [20], in order to stimulate local economies, local governments expand infrastructure development. With the rise in the level of financial technology investment, they tend to cooperate with social capital. At the same time, as the principal force of technological innovation, private enterprises are positively affected by financial and technological investment and then attracted to infrastructure construction projects developed by the government. In this way, the potential impact of the government and the cooperative development of the PPP model is effectively promoted.

In addition, in the context of Chinese-style fiscal decentralization, there has been diversified target competition among governments. Since 1994, intergovernmental competition has gradually manifested itself as fiscal competition [21]. Since fiscal decentralization has a restraining effect on fiscal technology investment, intergovernmental competition can alleviate this effect. This is an important condition for promoting regional economic growth and will lead to a certain degree of innovation and comparison between regions [22]. This effect is likely to cause local governments to move the financial technology investment they can control to the high-tech innovation field, and the investment in the infrastructure field will be weakened accordingly, which may have a negative impact on the development process and efficiency of the PPP model. Therefore, when exploring the relationship between government fiscal expenditure on science and technology and the development of local PPP models, the level of competition among governments is also a factor that needs to be considered. As an innovative method of investment and financing, whether the development of the PPP model is affected by technological innovation and whether it is related to the amount and direction of government fiscal expenditure on science and technology are questions that have not yet been studied by scholars. In the context of the Chinese-style fiscal decentralization policy, will the "promotion tournament" and the imbalance of power and financial power caused by intergovernmental competition affect the relationship between financial technology investment and the development of the PPP model? Will it further affect the PPP model? What is the internal mechanism of the application in this area? This research gap needs to be narrowed.

By exploring the relationship between government fiscal expenditure on science and technology and the development of local PPP models, this paper investigates whether the relationship can be affected by intergovernmental competition. The research begins with the internal factors of government finance, investigates the factors affecting the effectiveness of the implementation of the PPP model and aims to provide decision-making 
references for the direction of financial investment and financing behaviors of local governments. The actual level of competition between governments is determined to conduct in-depth research on the impact of the relationship. The integration of financial technology investment, intergovernmental competition and the internal mechanism of the development of local PPP models is comprehensively considered, considering the multi-target competitive environment. This has practical and theoretical significance for the development of government financial technology investment, the application of regional PPP models and their mechanisms of influence.

\subsection{Innovation and Research Significance}

The possible innovations and research significance of this article include the following: (1) starting from the government's fiscal expenditure on science and technology, we explore whether the allocation of financial investment by various governments in China affects the selection motivation and decision-making processes of local government financing behavior and provide a reference for the direction of financial investment; (2) we explore the factors influencing the successful application of the PPP model and provide practical decision-making references for the financing behavior of local government infrastructure construction from the perspective of the impact of financial technology investment; and (3) by determining the competition among governments, the relationship between fiscal investment structure and the local government's choice of PPP model is explored.

We comprehensively consider the three factors of government governance, economic disparity between regions and the financial sustainability of infrastructure investment. The integration of the tripartite influence mechanism has certain theoretical significance for the improvement of the theoretical system of the PPP model and the establishment of the internal mechanism. This has certain practical significance for the improvement of the financial investment structure and the application of the local government PPP model and provides decision-making suggestions for the sustainable development of the city.

Based on the background introduction and literature review, this article finds theoretical gaps and practical needs. Through the theoretical analysis of the internal influence of government financial science and technology investment on the development of the infrastructure PPP model, we introduce intergovernmental competition factors as intermediary variables and put forward research hypotheses. According to the research design, we conduct empirical research using collected data. On the basis of the main inspection, conclusions are drawn through an analysis of the results' robustness and further inspection. Then, we put forward policy recommendations, as well as research limitations and feasible directions for future research.

\section{Theoretical Analysis and Research Hypothesis}

2.1. The Impact of Government Fiscal Expenditure on Science and Technology on the Development of Local Infrastructure PPP Models

2.1.1. Government Fiscal Expenditure on Science and Technology Increases the Willingness of Enterprises to Cooperate with the Government in Infrastructure Projects

As a policy tool, government fiscal expenditure on science and technology can guide and promote industrial development and, to a certain extent, can reduce the risk of government failure, but it will not directly promote the optimization and upgrading of industrial structures [23]. As enterprises are the principal force of technological innovation, the level of government investment in science and technology can have a positive effect on the technological innovation measures of enterprises [24,25]. At the same time, government investment in science and technology also has leverage and spillover effects on enterprises [26]. Under the guidance of the government, enterprises will direct their technological innovation and goals to the field of infrastructure construction. Furthermore, in the cooperation process of the PPP model, the technological innovations of private companies can reduce the overall development costs of a project [27]. With the endorsement of preferential policies for government investment in science and technology, social capital can greatly increase social trust through structural trust and further expand a company's social 
network. This can reduce the transaction costs of technology spillover and technology dissemination, promote the technological progress of enterprises and thus increase the total factor productivity, prompting companies to have sufficient incentives to participate in government-invested infrastructure projects. With technological innovation, private enterprises will be willing to consider cooperation with the government, and the tendency to participate in government infrastructure construction will be reinforced, laying the foundation for the establishment and development of the infrastructure PPP model in the local area.

2.1.2. Government Fiscal Expenditure on Science and Technology Will Guide the Direction of Enterprise Technological Innovation

The related fields of infrastructure and independent innovation are important parts of government financial investment. Private enterprises will change their own R\&D investment under the influence of government fiscal expenditure on science and technology. Other technological inputs have a crowding-out effect $[28,29]$, which means that, to a certain extent, private enterprises will be influenced by the government's guidance, independent innovation will be crowded out and cooperation will tend to grow. The learning and absorptive capacity of enterprises prompts them to actively respond to government infrastructure projects. Companies with strong technological innovation capabilities respond more quickly to the external environment and find it easier to acquire capabilities that can increase their innovation performance and consolidate their competitive advantages [30]. Knowledge is an important foundation for innovation and at the same time the most important resource of an enterprise, because all valuable creations will come from innovation, and innovation is the result of knowledge application [31]. The absorptive capacity of enterprises leads different organizations to have different abilities to assimilate and copy new knowledge from the outside world [32]. Enterprises with a higher absorptive capacity can manage knowledge spillovers more effectively, which may transform knowledge spillovers into innovation results [33]. Internal R\&D, personnel training and innovation cooperation all affect absorptive capacity [34]. When supported by government financial investment in science and technology, different companies will respond to the external environment because of their absorptive capacity and will be affected by government input, which will change the internal development direction of the company, such as internal R\&D and personnel training. After receiving the support of government fiscal expenditure on science and technology, private enterprises will develop in the direction of government financial support and commit targeted investments in response to the government's capital investment field. Therefore, in the initial stage of the government's bidding for infrastructure construction PPP projects, private enterprises are enthusiastic; market transaction friction and transaction costs are reduced, promoting the successful implementation of the infrastructure PPP model.

\subsubsection{The Innovation of the Government Financing Model Guides the Change of Infrastructure Investment and Financing Structure}

Different regions have different levels of government fiscal expenditure on science and technology. In the context of China's political "promotion championship", local governments tend to make full use of their own financial investment rights to invest in public service construction to drive economic performance. For this purpose, the local government shifts the focus of resource allocation to infrastructure construction fields that are closely related to people's livelihood [35,36]. The capital needed is relatively large and the pressure increases accordingly, meaning that the PPP innovative investment model, which can share risks and benefits, is a promising approach. Currently, China remains at a low level in terms of infrastructure construction investment, and the degree of diversification and sharing is also not high. Development financial models and systems have emerged accordingly [37]. Meanwhile, government investment in science and technology has spatial spillover effects in different regions. The phenomenon of "neighborhood imitation" will occur in the application of financial science and technology investment in various 
regions [38], and the nearby areas will imitate the innovative approaches and methods of leading regions. This will have a positive effect on the successful development of the infrastructure PPP model.

For private companies, the PPP model enables them to gain public visibility and enjoy preferential government policies [39] and thus further gain widespread social influence. Through the participation of private capital, the technical and economic feasibility of PPP projects can be enhanced, the financial pressure of local governments can be relieved and the transformation of local government functions can be realized. The cooperative relationship between the two parties in the PPP model means that they can complement each other, integrate technical resources, ease local financial pressures, improve project construction and operation efficiency and promote technological innovation in the field of infrastructure. In the case that the public and private parties complement each other, both parties have the incentive to promote the successful development of the PPP model.

In summary, the growth of government fiscal expenditure on science and technology will promote the level of technological innovation of private enterprises in the region and can guide the innovation direction and industrial structure of enterprises, which will attract enterprises to innovate in areas that are in demand by the government. Private enterprises will show great enthusiasm for participating in government public construction projects. The technological innovation level of private enterprises can reduce the overall cost of government-enterprise cooperation projects, thus promoting the sound development of the PPP model in the region and increasing its implementation rate. In addition, with the decentralization of fiscal power, local governments have the right to control the direction of fiscal technology investment, and they also have the right to try innovative financing methods. Therefore, as the demand for infrastructure construction continues to expand, the PPP model is able to release the financial pressure of local governments, maintain fiscal balance, integrate the unique advantages of both parties, share risks and benefits, and so on. Both local governments and social capital tend to choose this financing model, which is conducive to the development and success of the PPP model.

Accordingly, this article proposes the following hypotheses:

Hypothesis H1A. Government fiscal expenditure on science and technology is positively correlated with the investment quantity of PPP model investment in local regional infrastructure.

Hypothesis H1B. Government fiscal expenditure on science and technology is positively correlated with the amount of investment through the PPP model in local regional infrastructure.

\subsection{The Relationship between Intergovernmental Competition and the Impact of Government Financial Technology Investment on the Development of Local PPP Model}

Against the background of the developmental financial model in the infrastructure field, financial technology investment has the ability to activate the market, drive social capital and improve management. However, in the case of intergovernmental competition, investment in production-oriented infrastructure construction will affect other parties [40]. In the process of regional economic integration, local governments have gradually become independent economic entities with interests and decision-making rights. In addition, under the guidance of Chinese-style fiscal decentralization, there exists competition among governments and a demand for market-oriented expansion, which drives the main economic growth level of each region [41,42].

The competitive environment created by fiscal decentralization in China affects the choices of the optimal decision-makers regarding resource allocation by various local governments [43], and the administrative expenditure structure and decision-making power of local governments differ. However, the income rights are still mostly concentrated in the central government, meaning that in fact there is still an imbalance in terms of power and financial power [44]. Therefore, in the process of competition among regions, local governments prefer measures that can boost the level of local economic conditions in order 
to balance fiscal revenue. Based on this, inter-governmental competition can be divided into vertical competition with unbalanced power and financial power. Driven by the political "promotion championship", local governments at the same level adopt horizontal competition with different levels of financial investment allocation in order to improve their competitiveness [15].

\subsubsection{Horizontal Competition}

Driven by the horizontal competition, local governments use their own financial investment to control power, seeking higher economic benefits and performance levels to enhance their own competitiveness. Although local governments vigorously develop infrastructure construction on this basis, fiscal decentralization can have a restraining effect on local fiscal investment in science and technology, and there will be an innovation and comparison effect between governments. Therefore, the government will devote financial technology investment to high-tech fields. In this process, however, investment in the infrastructure sector will be negatively affected, thus degrading the relationship between financial technology investment and the development of local PPP models and inhibiting the promotion of the PPP model.

\subsubsection{Vertical Competition}

Driven by the vertical competition, the investment impact of the central government is weaker than that of local governments. The central government's investment in infrastructure decreases [45], and local governments' financial pressures correspondingly increase. In the case of a mismatch between power and financial power, the actual enthusiasm of local governments for financial investment will be shifted. In the case of "top-down" competition, the organizational environment of the local government is affected by the higher-level government, and the local government prefers to win authoritative recognition and public recognition as the goal of the operating mechanism, so it pursues multi-task goal competition [46]. In this environment, the structure of local government investment in financial technology becomes more multi-dimensional, and its investment in technological innovation in infrastructure construction is reduced. Furthermore, the application promotion effect of the PPP model is also weakened to a certain extent.

Accordingly, this paper also proposes the following hypothesis:

Hypothesis H2. The stronger the level of intergovernmental competition, the weaker the positive correlation between the level of government fiscal expenditure on science and technology and the development of infrastructure PPP model investment.

\section{Research Design}

\subsection{Model Assumption}

To verify the main hypothesis, this article refers to the research of Hammami et al., Chen Shijin and Liu Hao, Luo Yu et al., Jia Junxue et al., etc. [47-50]. The main regression equation is defined as

$$
P N=\alpha_{0}+\alpha_{1} \text { TFI }+\sum \lambda_{k} \text { Control }_{k}+\varepsilon
$$

where TFI is the variable of regional fiscal science and technology expenditure, $\alpha_{1}$ reflects the influence of the local government's fiscal expenditure on science and technology on the decision-making of the local governments' selection of a PPP financing model and Control represents the various control variables involved in the model, mainly including the local education level of each region $(E D U)$, the financial development level of each region (FIN), the degree of inflation of each region $(C P I)$, the degree of industrialization of each region (IND) and the level of opening to the outside world of each region (OPEN). 
In order to verify Hypothesis H2, referring to the research of Hammami et al., Liu Chang et al., Wang Zhuojun and Guo Xuemeng $[14,47,51]$, the regression equation is defined as

$$
P N=\alpha_{0}+\alpha_{1} \text { TFI }+\alpha_{2} C M P T+\alpha_{3} \text { TFI } * \text { CMPT }+\sum \lambda_{k} \text { Control }_{k}+\varepsilon
$$

where TFI is the variable of regional fiscal science and technology expenditure, CMPT is a measurement variable of regional government competition, $T F I^{*} C M P T$ is a crossover between fiscal science and technology expenditure and intergovernmental competition, $\alpha_{1}$ reflects local government fiscal science and technology expenditures, $\alpha_{2}$ reflects the influence of the degree of intergovernmental competition on the government's decision to choose a PPP financing mode and $\alpha_{3}$ reflects the moderating effect of intergovernmental competition on the level of government financial technology expenditure and the decision-making effect of local governments when choosing PPP financing models. Control represents the various control variables involved in the model, mainly including the local education level in each region (EDU), the financial development level in each region (FIN), the degree of inflation in each region (CPI), the degree of industrialization in each region (IND) and the opening-up level of each region (OPEN).

\subsection{Variable Definition}

\subsubsection{The Explained Variable}

The level of development of the PPP model in each local area is measured by the quantity of PPP projects $(P N)$ and the amount of investment $(P I)$ of PPP projects in each province, autonomous region and municipality directly under the Central Government (hereinafter referred to as the "province") in each year in the field of infrastructure. After considering the logarithm, the quantity of PPP projects in each region, the amount of investment in projects developed by the PPP model in this article and the investment amount data are all from the PPI database published by the World Bank.

\subsubsection{Explanation of Variables}

Fiscal science and technology expenditure (TFI): Referring to Chen Shaohui [52], the total amount of financial science and technology investment by each local government does not represent the local government's fiscal expenditure on science and technology, and internationally accepted relative indicators are selected. Therefore, this article uses the proportion of regional fiscal technology investment in local GDP to explain the variable of fiscal technology investment.

Intergovernmental competition (CMPT): In China and abroad, variables such as the amount of foreign direct investment per capita, the relative actual tax rate of foreign-funded enterprises and the degree of opening up to the outside world have been used to explain political competition. Referring to the view of Chen Yaping and Han Fengqin [22], China has a certain degree of local protectionism, and competition among local governments can be reflected by the level of foreign direct investment. Therefore, considering the changes in exchange rates and prices, this article chooses the proportion of foreign direct investment in each region to the national foreign direct investment as a substitute variable for intergovernmental competition.

\subsubsection{Control Variables}

Drawing on the research of Liu Chang et al. [15], in order to carefully analyze the impact of government fiscal expenditure on science and technology on the development of local PPP models, this paper sets up a series of control variables (Control), including the following:

1. The local education level $(E D U)$ in each region, measured by the ratio of each province's annual education expenditure to the province's GDP from 2008 to 2018; 
2. The level of financial development (FIN) in each region, measured by the ratio of the total amount of loans from all financial institutions in each province to the province's GDP from 2008 to 2018;

3. The degree of inflation $(C P I)$ in each region, which is measured by the consumer price index of each province from 2008 to 2018-a macroeconomic indicator;

4. The degree of industrialization (IND) of each region, which is measured by the ratio of the province's secondary industry GDP to the province's total GDP from 2008 to 2018;

5. The level of opening up (OPEN) in each region, measured by the ratio of the total import and export volume of each province to the total GDP of the province during 2008-2018.

\subsection{Sample Source}

Based on the PPI database published by the World Bank, the regions are limited to 31 provinces in China, and the time range is limited to 2008-2018. After excluding PPP projects with incomplete information, the total sample size of this article is 372 . In this paper, the data on the number of projects and the amount of investment reflecting the development of the local regional PPP model are all from the World Bank's PPI database; the government fiscal investment in science and technology, intergovernmental competition data and other control variables are all from the China Financial Statistical Yearbook, China Statistical Yearbook and various provincial databases.

\section{Empirical Results and Discussions}

\subsection{Sample Descriptive Statistics}

The descriptive statistics of the variables selected in this paper are shown in Table 1. It can be seen that, in the development of PPP models in various regions of China, the maximum number of items is 13 and the minimum is 0 . The maximum investment amount of the PPP model (using the logarithm in this paper) is 9.403 and the minimum is 0.620 . The data shows that there are certain differences in the development of the PPP model among various regions and provinces in China.

Table 1. Variable descriptive statistics.

\begin{tabular}{cccccc}
\hline Variable & $\mathbf{N}$ & Mean & SD & Min & Max \\
\hline$P N$ & 372 & 2.005 & 2.251 & 0 & 13 \\
$P I$ & 243 & 4.982 & 1.558 & 0.620 & 9.403 \\
$T F I$ & 372 & 0.00424 & 0.00260 & 0.00135 & 0.0143 \\
$C M P T$ & 372 & 0.0617 & 0.0645 & 0 & 0.320 \\
$E D U$ & 372 & 0.0415 & 0.0233 & 0.0178 & 0.173 \\
$F I N$ & 372 & 1.257 & 0.443 & 0.533 & 3.083 \\
$I N D$ & 372 & 0.358 & 0.114 & 0.0444 & 0.530 \\
OPEN & 372 & 0.290 & 0.340 & 0.0146 & 1.667 \\
CPI & 372 & 1.027 & 0.0181 & 0.977 & 1.101 \\
\hline
\end{tabular}

Note: The data in the table come from the World Bank PPI database, China Financial Statistical Yearbook, China Statistical Yearbook and various provincial databases and were obtained through empirical processing by STATA.

In addition, the government's fiscal technology investment level (TFI) is between $0.135 \%$ and $1.43 \%$, which is a wide range, indicating that there are large differences in the level of fiscal technology investment between provinces in China. The value of intergovernmental competition $(C M P T)$ is between 0 and 0.32 , indicating that the level of competition among Chinese provinces is not the same. Other control variables also differ between provinces, but the standard deviation results are within an acceptable range, proving that the data can provide a basis for the empirical analysis of this article. 


\subsection{Analysis of Empirical Results}

Considering the fact that some provinces and regions in China have not used the PPP model in some years (the value is 0 ), for the empirical analysis of the number of PPP model projects in this article we used the method of Chen Shijin and Liu Hao [48] and adopted the Poisson regression model. According to the Hausman test, a fixed-effect regression model was selected. As shown in Table 2, the full sample test results (columns (1) and column (2)) reflect the main regression test results. The results show that the government's fiscal expenditure on science and technology affects the development of the PPP model between provinces and regions. The impact of both quantity and investment amount is significant at the $1 \%$ confidence level, and the coefficient is positive, indicating that the level of local government fiscal expenditure on science and technology has a positive and significant impact on the development of the PPP model in the region. When a region's fiscal expenditures on science and technology are high, the development level of the PPP model in the region is higher. To verify the previous analysis, the higher the level of financial technology investment in a region, the more it will promote the innovation level of enterprises in the region. Moreover, when financial technology investment has a crowding-out effect on large and medium-sized enterprises, the independent innovation level of enterprises may be affected. Enterprises will be more inclined to carry out technological innovation and investment innovation in accordance with the direction of the government and more willing to participate in infrastructure construction projects hosted by the government to promote the development of the PPP model. On the other hand, the higher the level of regional fiscal expenditure on science and technology, the higher the efficiency of local governments; driven by financial pressure, they will be more willing to try innovative financing models and more inclined to seek investment from social capital to promote the development of the PPP model. Based on this, hypotheses H1A and H1B can be verified.

Table 2. Government financial science and technology revenue, intergovernmental competition and the development of local PPP models.

\begin{tabular}{ccccc}
\hline & \multicolumn{2}{c}{ Full Sample } & $\begin{array}{c}\text { Strong Competition among } \\
\text { Governments }\end{array}$ & $\begin{array}{c}\text { Weak Competition among } \\
\text { Governments }\end{array}$ \\
\cline { 2 - 5 } Variable & $\mathbf{P N}$ & $\mathbf{P I}$ & $\mathbf{P I}$ & $\mathbf{P I}$ \\
& $\mathbf{( 1 )}$ & $\mathbf{( 2 )}$ & $\mathbf{( 3 )}$ & $\mathbf{( 4 )}$ \\
\hline TFI & $267.3247^{* * *}$ & $320.6766^{* * *}$ & 156.514 & $508.2243^{*}$ \\
& -2.7403 & -3.1951 & -0.8189 & -1.7521 \\
EDU & $40.5034^{*}$ & -9.5772 & -49.8285 & -13.6968 \\
& -1.6587 & $(-0.3727)$ & $(-0.9208)$ & $(-0.3913)$ \\
FIN & -0.5524 & 0.0269 & 1.1683 & -0.299 \\
& $(-1.0883)$ & -0.0438 & -0.5704 & $(-0.3269)$ \\
IND & $-6.6478^{* *}$ & $-6.5489 * *$ & $-9.9829 *$ & $-6.14866^{*}$ \\
& $(-2.4832)$ & $(-2.4187)$ & $(-1.8291)$ & $(-1.6691)$ \\
OPEN & 0.0517 & -0.9876 & -0.224 & -2.6384 \\
& -0.0463 & $(-0.6626)$ & $(-0.1066)$ & $(-0.7303)$ \\
CPI & 10.0109 & -1.7048 & -4.7635 & 0.7308 \\
& -1.6154 & $(-0.2847)$ & $(-0.4418)$ & -0.0918 \\
Cons & -8.0272 & 8.5609 & 13.8196 & 5.9185 \\
$\mathrm{R}^{2}$ & $(-1.2403)$ & -1.3503 & -1.2151 & -0.6961 \\
$\mathrm{~N}$ & 0.0669 & 0.1649 & 0.2698 & 0.0815 \\
\hline
\end{tabular}

Note: ${ }^{* * *}, * * *$ represent the significance level of $1 \%, 5 \%$ and $10 \%$ respectively. The data in the table come from the World Bank PPI database, China Financial Statistical Yearbook, China Statistical Yearbook and various provincial databases and were obtained through empirical processing by STATA.

This article examines the crossover between government competition and government financial technology investment through the method of grouping to test whether the degree of competition between governments will affect the relationship between fiscal technology investment and the local development of the PPP model. As shown in Table 2, 
column (3) and column (4) reflect the results of group inspections according to the level of intergovernmental competition. After grouping, the number of items has fewer indicators, which cannot reflect the true state, and the result is not significant, so it is omitted. From the results of column (3), it can be seen that when the competition between governments is strong, the influence of the government's financial technology investment in the local regional development PPP model is no longer significant, and the positive coefficient is smaller than that of the full sample. The results of column (4) show that when the intensity of intergovernmental competition is weak, the positive impact of fiscal science and technology investment on the development of the local PPP model is still significant at the $10 \%$ confidence level, and the positive coefficient is larger than that of the whole sample. It can be concluded that the degree of competition among governments will have a restraining effect on the positive relationship between government fiscal expenditure on science and technology and the development of local PPP models. As mentioned above, in the context of fiscal decentralization and competition, there are varying degrees of competition between governments. Competition can promote the enhancement of market functionality and have an impact on the direction of technology investment. The horizontal competition between regions prompts local governments to devote more financial and technological investment to technological innovation and direct less investment to infrastructure construction. This will affect the development of the PPP model, and the effect of financial technology investment on the development of the PPP model will be weakened. In addition, the vertical competition between the superior and the subordinate causes the local government's power and financial power to be mismatched, and the real power to control financial technology investment will be affected by competition, suppressing the positive impact of the investment of the private party on the application of the PPP model. Based on this, hypothesis $\mathrm{H} 2$ is verified.

\subsection{Robustness Test}

On the basis of the main test of this article, drawing on the different measurement standards of intergovernmental competition by related scholars, we choose per capita foreign direct investment to explain the heterogeneity of competition among local governments and substitute the main regression and cross-product model for a robustness test [53]. As shown in Table 3, after substituting variables for per capita foreign direct investment, results similar to those of the original test can be obtained (column (3) and column (4)). Within the regional groupings where intergovernmental competition is relatively strong, the relationship between the local development of the PPP model and the financial technology investment is not significant, and the coefficient is smaller than that of the full sample. In regions with weaker competition, the positive correlation between the amount of money developed by the PPP model is significant at the $10 \%$ confidence level, and the coefficient is larger than that of the full sample. Therefore, it can be proven that intergovernmental competition has an inhibitory effect on the positive impact of fiscal technology investment on the degree of local development of the PPP model. To verify hypothesis $\mathrm{H} 2$, the conclusion that a greater intensity of intergovernmental competition leads to a weaker positive correlation between fiscal technology investment and the development of the PPP model in the local area is robust.

In addition, due to administrative planning and policy adjustments in a small number of regions, there may be some outliers in regional data. Therefore, this article draws on the way related scholars handle county-level data and submits the main regression data to a robustness test; the test result is consistent with the main regression result, which proves to be robust. The specific results are not listed in the article. 
Table 3. Robustness test with per capita foreign direct investment as a variable.

\begin{tabular}{|c|c|c|c|c|}
\hline \multirow{2}{*}{ Variable } & \multicolumn{2}{|c|}{ Full Sample } & \multirow{2}{*}{$\begin{array}{c}\begin{array}{c}\text { Strong Competition among } \\
\text { Governments }\end{array} \\
P I \\
(3) \\
\end{array}$} & \multirow{2}{*}{$\begin{array}{c}\text { Weak Competition among } \\
\text { Governments } \\
P I \\
(4) \\
\end{array}$} \\
\hline & $\begin{array}{l}P N \\
(1)\end{array}$ & $\begin{array}{l}P I \\
(2)\end{array}$ & & \\
\hline TFI & $\begin{array}{c}267.3247^{* * *} \\
-2.7403\end{array}$ & $\begin{array}{c}320.6766^{* * *} \\
-3.1951\end{array}$ & $\begin{array}{r}237.9307 \\
(1.1050)\end{array}$ & $\begin{array}{c}414.7643 \text { * } \\
(1.9094)\end{array}$ \\
\hline$E D U$ & $\begin{array}{c}40.5034 \text { * } \\
-1.6587\end{array}$ & $\begin{array}{c}-9.5772 \\
(-0.3727)\end{array}$ & $\begin{array}{l}-99.0699 \\
(-1.2225)\end{array}$ & $\begin{array}{l}14.6618 \\
(0.4786)\end{array}$ \\
\hline FIN & $\begin{array}{c}-0.5524 \\
(-1.0883)\end{array}$ & $\begin{array}{c}0.0269 \\
-0.0438\end{array}$ & $\begin{array}{c}1.2256 \\
(0.9105)\end{array}$ & $\begin{array}{c}-0.5058 \\
(-0.6151)\end{array}$ \\
\hline$I N D$ & $\begin{array}{l}-6.6478 * * \\
(-2.4832)\end{array}$ & $\begin{array}{l}-6.5489 * * \\
(-2.4187)\end{array}$ & $\begin{array}{c}-4.2113 \\
(-0.5886)\end{array}$ & $\begin{array}{l}-7.3986^{* *} \\
(-2.2917)\end{array}$ \\
\hline OPEN & $\begin{array}{c}0.0517 \\
-0.0463\end{array}$ & $\begin{array}{c}-0.9876 \\
(-0.6626)\end{array}$ & $\begin{array}{c}-1.8119 \\
(-0.8167)\end{array}$ & $\begin{array}{c}-2.6870 \\
(-0.7756)\end{array}$ \\
\hline CPI & $\begin{array}{l}10.0109 \\
-1.6154\end{array}$ & $\begin{array}{c}-1.7048 \\
(-0.2847)\end{array}$ & $\begin{array}{l}-10.5836 \\
(-0.8119)\end{array}$ & $\begin{array}{c}2.2218 \\
(0.3107)\end{array}$ \\
\hline _cons & $\begin{array}{c}-8.0272 \\
(-1.2403)\end{array}$ & $\begin{array}{c}8.5609 \\
-1.3503\end{array}$ & $\begin{array}{l}18.9169 \\
(1.4330)\end{array}$ & $\begin{array}{c}4.2971 \\
(0.5622)\end{array}$ \\
\hline $\mathrm{R}^{2}$ & 0.0669 & 0.1649 & 0.2826 & 0.1016 \\
\hline $\mathrm{N}$ & 372 & 243 & 76 & 167 \\
\hline
\end{tabular}

Note: ${ }^{* * *}, * *, *$ represent the significance level of $1 \%, 5 \%$ and $10 \%$ respectively. The data in the table come from the World Bank PPI database, China Financial Statistical Yearbook, China Statistical Yearbook and various provincial databases and were obtained through empirical processing by STATA.

\subsection{Further Inspection}

4.4.1. The Impact of Regional Differences on Government Fiscal Expenditure on Science and Technology and the Development of Local PPP Models

Due to regional differences, the impact of government investment in science and technology on enterprise innovation is regionally heterogeneous [54], and thus its impact on the development of local PPP models also varies. There are inherent differences in the development levels, policy systems, resource endowments, urbanization development processes, population levels and other factors of various regions, which cause different levels of influence on the development of local PPP models to be exerted by government financial technology investment in different regions.

The efficiency of government fiscal expenditure on science and technology in the eastern region shows greater advantages than the central and western regions, while the level in the central and western regions is basically the same [55]. The level of openness, development foundation and infrastructure construction in the eastern region is higher than that in the middle and western regions [56]. In regions with higher economic and technological levels, the performance of government investment in science and technology is also higher, and the efficiency of government investment is better than that of the market. With higher investment [57], government investment in science and technology has a greater impact on enterprises and leads to more diversified goals. In addition, under the influence of the spillover effect of the government's fiscal expenditures on science and technology, the "neighborhood imitation" phenomenon takes effect among different regions in order to improve the investment efficiency; however, this effect is relatively weak in the more developed eastern regions.

Specifically, the economic development foundation of the eastern region is relatively high, the construction and development of infrastructure has gradually stabilized and the required fiscal gap is relatively small. In addition, in the intergovernmental competition environment brought about by fiscal decentralization, the eastern region is gradually paying increased attention to all-round competition [58]. In the central and western regions, there is still room for economic development and the inherent development level of public construction, and the fiscal gap is larger than that of the eastern regions. Therefore, the central and western regions focus on infrastructure construction fields that are closely related to people's livelihood and can lead to fiscal revenue. In addition, the level of technological innovation in the middle and western regions is relatively low, and the 
development of private enterprises in the region is more susceptible to government trends. Therefore, in the process of structural allocation of fiscal expenditures on science and technology, the central and western regions' governments will invest more in the field of infrastructure and private enterprises will be more active in participating in the PPP model, which will promote development.

Since the level of infrastructure construction has become relatively complete, when investing in new construction projects in the eastern region, a suitable model is chosen based on past experience and application, thereby weakening the motivation for innovative financing methods. When allocating fiscal expenditures on science and technology, less consideration is given to the application of infrastructure construction, and the government is more inclined to high-tech technological innovation. However, in the middle and western regions, the geographical environment, land resources and development level are all subject to some inherent restrictions. In the context of government competition, local governments will choose to use their limited financial and technological investment opportunities to invest in infrastructure to enhance their competitiveness. They are also more active in cooperating with private companies, and the level of government fiscal expenditure on science and technology has a strong impact on the application of the PPP model.

In order to explore whether there are differences in the influence of government financial technology investment on the development level of local PPP models in different regions, this paper conducts a further test. According to regional differences, this paper merges the middle and western regions into one region and divides the data into two groups - the eastern region and the middle and western regions-for testing. The results are shown in Table 4. In the middle and western regions, government fiscal expenditure on science and technology has a positive and significant impact on the amount and quantity of local PPP model development. The number of projects is significant at the $5 \%$ confidence level, and the investment amount is significant at the $1 \%$ confidence level. In the eastern region, the main test relationship does not show a significant result, and the positive coefficient is lower than that in the central and western regions. The test results prove that there are differences in the impact of government financial technology investment on the development of local PPP models in different regions. Based on the previous analysis, the main test relationship in the central and western regions is positively significant, and the view that the relationship in the eastern region is not significant is verified.

Table 4. The impact of regional differences on government fiscal expenditure on science and technology and the development of local PPP models.

\begin{tabular}{|c|c|c|c|c|}
\hline \multirow[b]{2}{*}{ Variable } & \multicolumn{2}{|c|}{ East } & \multicolumn{2}{|c|}{ Mid and West } \\
\hline & $\begin{array}{r}P N \\
(1)\end{array}$ & $\begin{array}{l}P I \\
(2)\end{array}$ & $\begin{array}{l}P N \\
(3)\end{array}$ & $\begin{array}{l}P I \\
(4)\end{array}$ \\
\hline$T F I$ & $\begin{array}{c}237.7955 \\
(1.5253)\end{array}$ & $\begin{array}{l}70.0087 \\
(0.2726)\end{array}$ & $\begin{array}{c}278.8727 * * \\
(2.0993)\end{array}$ & $\begin{array}{c}345.2800 * * * \\
(3.0843)\end{array}$ \\
\hline$E D U$ & $\begin{array}{l}-0.3248 \\
(-0.0067)\end{array}$ & $\begin{array}{l}-30.0469 \\
(-0.4191)\end{array}$ & $\begin{array}{l}43.9681 \\
(1.4289)\end{array}$ & $\begin{array}{c}-5.4609 \\
(-0.1889)\end{array}$ \\
\hline FIN & $\begin{array}{c}0.1000 \\
(0.1151)\end{array}$ & $\begin{array}{c}1.5290 \\
(1.2346)\end{array}$ & $\begin{array}{c}-0.6684 \\
(-0.9991)\end{array}$ & $\begin{array}{c}-0.4881 \\
(-0.6496)\end{array}$ \\
\hline$I N D$ & $\begin{array}{c}-11.9639 * * \\
(-2.3852)\end{array}$ & $\begin{array}{l}-4.3280 \\
(-0.6199)\end{array}$ & $\begin{array}{l}-5.3627 \\
(-1.5453)\end{array}$ & $\begin{array}{c}-8.7953 * * * \\
(-2.8293)\end{array}$ \\
\hline OPEN & $\begin{array}{c}0.7030 \\
(0.5495)\end{array}$ & $\begin{array}{l}-3.0229 \\
(-1.2266)\end{array}$ & $\begin{array}{c}0.0332 \\
(0.0095)\end{array}$ & $\begin{array}{c}3.8563 \\
(1.0439)\end{array}$ \\
\hline$C P I$ & $\begin{array}{l}15.8465 * \\
(1.9454)\end{array}$ & $\begin{array}{c}-3.0661 \\
(-0.2812)\end{array}$ & $\begin{array}{c}5.4373 \\
(0.6049)\end{array}$ & $\begin{array}{c}-0.1284 \\
(-0.0173)\end{array}$ \\
\hline _cons & $\begin{array}{l}-12.1219 \\
(-1.3959)\end{array}$ & $\begin{array}{l}10.1208 \\
(0.9052)\end{array}$ & $\begin{array}{l}-3.7841 \\
(-0.4053)\end{array}$ & $\begin{array}{c}7.4813 \\
(0.9446)\end{array}$ \\
\hline $\mathrm{R}^{2}$ & 0.1314 & 0.2091 & 0.0501 & 0.1769 \\
\hline $\mathrm{N}$ & 144 & 83 & 228 & 160 \\
\hline
\end{tabular}

Note: ${ }^{* *},{ }^{* *},{ }^{*}$ represent the significance level of $1 \%, 5 \%$ and $10 \%$ respectively. The data in the table come from the World Bank PPI database, China Financial Statistical Yearbook, China Statistical Yearbook and various provincial databases and were obtained through empirical processing by STATA. 
4.4.2. The Impact of Industry Differences on Government Fiscal Expenditures on Science and Technology and the Development of Local PPP Models

From the perspective of industrial differences, financial technology investment will have a negative impact on the relationship between private enterprise technology investment and performance [57] and will produce a crowding-out effect on the input of large and medium-sized enterprises [29]. Therefore, the impact of financial technology investment on industries with different technological innovation needs and scales is also different. Different industries have different technical requirements, degrees of monopoly and economic benefits that can be produced [35] and the behavioral decisions of local governments and private enterprises will also be affected by their different attributes.

In the context of the promotion mechanism described above, regional governments tend to develop more industrialized industries to obtain higher returns [59]. In order to enhance the capital competitiveness of local government officials during their tenure, the government is more inclined to develop environmental protection, water conservancy and other projects that can harvest more economic benefits than public service industries such as energy and transportation [60]. The gradual increase in urban population will expand the scale of existing cities; the public's demand for public travel is increasing day by day, and the problem of insufficient urban transportation supply has become increasingly prominent. The resulting traffic congestion, road congestion, environmental pollution and the inefficiency of the entire city's transportation have a huge impact on urban social and economic development processes and have become a major bottleneck restricting the sustainable development of a city. Therefore, under the restriction of the limited level of fiscal expenditure on science and technology, local governments will choose to develop economical infrastructure construction projects in winter, which will further affect their financing models and promote the application of PPP models in this industry.

In addition, the degree of government monopoly in various industries is different, and the enthusiasm of private enterprises to participate is also affected. In industries with a high level of government monopoly, such as the energy industry, although the PPP model has room for development, the government has higher control rights. When private capital is affected by government financial investment in technology, industry barriers caused by the monopoly will inhibit its enthusiasm for participation. In the transportation and water conservancy industries, the degree of government monopoly is relatively low [15]. While receiving government fiscal expenditure on science and technology, private enterprises also face less government intervention and are therefore more motivated to adjust their own development directions and investment fields. Therefore, under the guidance of the government, they are more actively involved in the government's desired construction projects.

According to previous test results, to explore whether the influence of government financial technology investment on the development of local PPP models is different between different industries, we conduct a further test based on industry attributes. By using the industry classification in the World Bank's PPI database, we divide the sample data into the three industries of energy, transportation and water conservancy and conduct group inspections on this basis. In Table 5, the results show that, in the energy industry, the influence of government financial technology investment on the development of local PPP models is not significant, and its coefficient is also small. In the transportation industry, the impact of government fiscal expenditure on science and technology on the number of projects and investment in local PPP model development is significant at the confidence levels of $1 \%$ and $10 \%$, respectively. In the water conservancy industry, although the impact on the number of projects developed by the PPP model is not significant, the impact on the investment amount is significant at the $5 \%$ confidence level. This indicates that there are differences in the influence of government financial technology investment on the development of local PPP models among different industries. In conclusion, the main test relationship is not significant in the energy industry, but in the transportation and water conservancy industries, there is a more significant positive relationship. 
Table 5. The impact of industry differences on financial technology investment and the development of local PPP models.

\begin{tabular}{ccccccc}
\hline & \multicolumn{2}{c}{ Energy } & \multicolumn{2}{c}{ Transport } & \multicolumn{2}{c}{ Water } \\
\cline { 2 - 7 } Variable & $\mathbf{P N}$ & $\mathbf{P I}$ & $\mathbf{P N}$ & $\mathbf{P I}$ & $\mathbf{P N}$ & $\mathbf{P I}$ \\
& $\mathbf{( 1 )}$ & $\mathbf{( 2 )}$ & $\mathbf{( 3 )}$ & $\mathbf{( 4 )}$ & $\mathbf{( 5 )}$ & $\mathbf{( 6 )}$ \\
\hline \multirow{2}{*}{ TFI } & 37.9996 & 147.1096 & $156.1443 * * *$ & $377.5883 *$ & 73.1809 & $212.7135 * *$ \\
& -0.5183 & -1.5766 & -3.1481 & -1.7604 & -1.2583 & -2.0482 \\
EDU & $66.4298^{* * *}$ & 24.8702 & -17.2999 & $-160.1002 * *$ & -8.6265 & $-62.2575 * *$ \\
& -3.6198 & -1.0594 & $(-1.3934)$ & $(-2.5525)$ & $(-0.5925)$ & $(-2.0365)$ \\
FIN & $-1.1307^{* * *}$ & -1.0482 & 0.3609 & 0.9013 & 0.2173 & 0.6382 \\
& $(-2.9640)$ & $(-1.5907)$ & -1.3986 & -0.7411 & -0.7182 & -0.855 \\
IND & 0.6449 & -4.2309 & $-7.4382 * * *$ & -3.0493 & 0.1455 & -3.4625 \\
& -0.3205 & $(-1.3412)$ & $(-5.4647)$ & $(-0.6336)$ & -0.0912 & $(-1.0602)$ \\
OPEN & 0.4492 & -1.9777 & 0.4673 & 0.7825 & -0.8648 & $-4.0740 * *$ \\
& -0.5355 & $(-1.1710)$ & -0.8235 & -0.3242 & $(-1.2997)$ & $(-2.2168)$ \\
CPI & -2.1428 & 0.3688 & $7.3367 * *$ & -10.5953 & 4.8171 & 3.6033 \\
& $(-0.4601)$ & -0.0535 & -2.3285 & $(-0.8582)$ & -1.3038 & -0.5662 \\
Cons & 1.1855 & 5.9551 & -4.9605 & 20.4766 & -4.2522 & 2.9334 \\
& -0.2437 & -0.8186 & $(-1.5075)$ & -1.5376 & $(-1.1020)$ & -0.4229 \\
$\mathrm{R}^{2}$ & 0.0469 & 0.0777 & 0.1863 & 0.1953 & 0.018 & 0.2147 \\
$\mathrm{~N}$ & 372 & 139 & 372 & 80 & 372 & 138 \\
\hline
\end{tabular}

Note: ${ }^{* * *},{ }^{* *},{ }^{*}$ represent the significance level of $1 \%, 5 \%$ and $10 \%$ respectively. The data in the table come from the World Bank PPI database, China Financial Statistical Yearbook, China Statistical Yearbook and various provincial databases and were obtained through empirical processing by STATA.

The results of further testing prove that this relationship is significant in the middle and western regions and the transportation and water conservancy industries, but in the eastern region and the energy industry, this relationship is not significant. This is not only relevant for the financial system of local governments; the improvement and reform provide a theoretical reference and a basis for the successful application of China's PPP model in the field of infrastructure.

\section{Conclusions}

This article uses the PPP project entry information of China's provinces from 2008 to 2018 in the World Bank PPI database as a research sample to explore the relationship between government governance, infrastructure investment and financing decisions; we further study the impact of government financial technology investment on the level of local regional development of PPP models. In the two-dimensional competition environment that exists between governments, whether the competition among local governments can promote or inhibit this relationship is also studied.

The results reveal that the level of fiscal expenditure on science and technology by each regional government has a significant positive impact on the development of the PPP model in the region and can promote cooperation between the government engaged in regional infrastructure construction and private enterprises, and this relationship can pass a robustness test. According to the influence of the fiscal decentralization system, this article introduces the factor of intergovernmental competition to explore whether the potential competitive environment between different regions affects the relationship between financial technology investment and the development of the PPP model in the region. The results show that the level of competition between governments inhibits this relationship; the stronger the competition among governments, the more diversified the development goals of local governments and the development of high-tech innovation, and the weaker the positive impact of government financial technology investment on the development of the PPP model.

In response to the guidance of General Secretary Xi's "double-cycle" in-depth reform direction, during the "new normal", regions should promote economic reforms and supplyside reform, seize strategic opportunities, promote the PPP model steadily and efficiently, increase its landing rate and increase government financial investment and infrastructure 
construction development efficiency. This article puts forward policy recommendations based on the research tests.

Regions should pay attention to the intensity and structure of government fiscal expenditure on science and technology. Local governments should appropriately increase investment in science and technology and carefully design investment structures, promote steady technological upgrading, strengthen cooperation with private companies and make targeted investment reforms to ensure the efficiency of the PPP model.

Regions should balance the efficiency and fairness of development in a competitive environment. Considering the development differences among different regions, the phenomenon of malicious competition in performance should be prevented. Win-win cooperation should be advocated, the financial investment mechanism should be improved, the simultaneous progress of resource allocation and achievement transformation should be promoted and efficiency and fairness should be given more attention.

Governments should strengthen the adjustment and assessment system of their service functions. Policy support related to fiscal expenditure on science and technology should be strengthened, and the concept of economic guidance should be adjusted. Technological cooperation and investment and financing mode cooperation should be innovated, and cooperation with private capital should be promoted to increase the enthusiasm of private capital to enter government construction projects.

However, the research in this paper still has limitations. Since the PPP model involves a variety of industry applications, the specific industry professional characteristics are still shallow. There is still room for research and improvements of the internal mechanism and the system construction of influencing factors. Some influencing factors of the internal mechanism are difficult to quantitatively study with data, and there are also subjective factors. Future research directions could involve building models for the entire influence mechanism system, improving control variables and quantifying subjective influence factors. The other structural factors of government fiscal expenditure should also be further studied in depth.

Funding: This work was supported by the National Natural Science Foundation of China under "Research on Performance Evaluation System of urban rail transit PPP mode based on resource 'passenger-value flow'”' (Number: 71973009).

Institutional Review Board Statement: Not applicable.

Informed Consent Statement: Not applicable.

Data Availability Statement: The data that support the findings of this study are available in Private Participation in Infrastructure (PPI) Database, "China Statistical Yearbook", "China Financial Statistics Yearbook", and provincial and municipal statistical yearbooks. These data were derived from the following resources available in the public domain: https://ppi.worldbank.org/en/ppi; http:/ / www.stats.gov.cn/tjsj/ndsj/.

Conflicts of Interest: The author declares no conflict of interest.

\section{References}

1. Vallejo, B.; Oyelaran-Oyeyinka, B.; Ozor, N.; Bolo, M. Open innovation and innovation intermediaries in Sub-Saharan Africa. Sustainability 2019, 11, 392. [CrossRef]

2. Martiniello, L.; Morea, D.; Paolone, F.; Tiscini, R. Energy Performance Contracting and Public-Private Partnership: How to Share Risks and Balance Benefits. Energies 2020, 13, 3625. [CrossRef]

3. Zhao, X.; Bai, Y.; Ding, L. Incentives for personal carbon account: An evolutionary game analysis on public-private-partnership reconstruction. J. Clean. Prod. 2021, 282, 125358. [CrossRef]

4. Carbonara, N.; Pellegrino, R. Public-private partnerships for energy efficiency projects: A win-win model to choose the energy performance contracting structure. J. Clean. Prod. 2018, 170, 1064-1075. [CrossRef]

5. Moro Visconti, R.; Morea, D. Healthcare digitalization and pay-for-performance incentives in smart hospital project financing. Int. J. Environ. Res. Public Health 2020, 17, 2318. [CrossRef] [PubMed]

6. Duranton, G.; Turner, M.A. Urban Growth and Transportation. Rev. Econ. Stud. 2012, 79, 1407-1440. [CrossRef] 
7. Sun, Y.; Chen, L.; Sun, H.; Farhad, T. Low-carbon Financial Risk Factor Correlation in the Belt and Road PPP Project. Financ. Res. Lett. 2020, 35, 101491. [CrossRef]

8. Bing, L.; Akintoye, A.; Edwards, P.J.; Hardcastle, C. The allocation of risk in PPP/PFI construction projects in the UK. Int. J. Proj. Manag. 2005, 23, 25-35. [CrossRef]

9. Galilea, P.; Medda, F. Does the political and economic context influence the success of a transport project? An analysis of transport public-private partnerships. Res. Transp. Econ. 2010, 30, 102-109. [CrossRef]

10. De Schepper, S.; Haezendonck, E.; Dooms, M. Understanding pre-contractual transaction costs for Public-Private Partnership infrastructure projects. Int. J. Proj. Manag. 2015, 33, 932-946. [CrossRef]

11. Lopes, A.I.; Caetano, T.T. Firm-level conditions to engage in public-private partnerships: What can we learn? J. Econ. Bus. 2015, 79, 82-99. [CrossRef]

12. Estache, A. PPI partnerships vs. PPI divorces in LDCs. Rev. Ind. Organ. 2006, 29, 3-26. [CrossRef]

13. Percoco, M. Quality of institutions and private participation in transport infrastructure investment: Evidence from developing countries. Transp. Res. Part A Policy Pract. 2014, 70, 50-58. [CrossRef]

14. Wang, Z.; Guo, X.; Li, H. Will the Regional Marketization Process Promote the Use of PPP Financing by Local Governments? An Empirical Study Based on Infrastructure Areas. Financ. Res. 2017, 10, 54-64.

15. Liu, C.; Guo, X.; Wang, Z. Chinese-style fiscal decentralization, fiscal transparency, and local governments' choice of PPP model. Inquiry Econ. Issues 2020, 2, 170-182.

16. Morea, D.; Balzarini, M. Bankability of a public private partnership in agricultural sector: A project in Sub Saharan Africa. Agric. Econ. 2019, 65, 212-222. [CrossRef]

17. Sun, H.; Pofoura, A.K.; Mensah, I.A.; Li, L.; Moshin, M. The role of environmental entrepreneurship for sustainable development: Evidence from 35 countries in sub-Saharan Africa. Sci. Total Environ. 2020, 741, 140132. [CrossRef]

18. $\mathrm{Xu}, \mathrm{X}$. Research on the Policy Effect of Government S\&T Investment on Enterprise S\&T Investment-Based on the Perspective of National Innovation System. Financ. Res. 2010, 10, 23-26.

19. Duan, X.; Cao, X. The Effectiveness Evaluation Method of Government Investment in Science and Technology Supporting Emerging Industries. Stud. Sci. Sci. 2010, 28, 1673-1676, 1730.

20. Zhou, L. Incentive and Cooperation of Government Officials in the Promotion Game-Also on the reasons for the long-standing problems of local protectionism and redundant construction in China. Econ. Res. 2004, 6, 33-40.

21. Bian, Z. Fiscal System, Economic Environment and China's Provincial-level Intergovernmental Competition Mechanism. Dongyue Lun Cong 2014, 35, 73-78.

22. Chen, Y.; Han, F. Fiscal Decentralization, Intergovernmental Competition, and Fiscal Technology Investment: An Empirical Study Based on Provincial Panel Data. Stat. Decis. 2020, 36, 138-142.

23. Chen, H.; Zheng, C. On the co-integration between government investment in science and technology and regional industrial structure. Search 2013, 2, 217-220.

24. Wu, Y. Research on the Impact of Government Investment in Science and Technology on Science and Technology Innovation: An Empirical Test Based on Panel Data from 1982 to 2010 in 40 Countries. Sci. Sci. Manag. Sci. Technol. 2014, 35, 16-22.

25. Xu, Z.; Shi, P. An Empirical Analysis of the Impact of Government Investment in Science and Technology on Enterprise R\&D Expenditure. Res. Dev. Manag. 2005, 3, 22-26.

26. Zhao, F.; Su, S.; Zou, S. Analysis of the impact of Chinese government investment in science and technology on R\&D investment in large and medium-sized industrial enterprises. Res. Dev. Manag. 2006, 2, 78-84.

27. Guo, W.; Zheng, Z. Proprietary Technology Transfer, Financing Cost Differences and PPP Optimal Equity Structure: An Empirical Study from Developing Countries. World Econ. Res. 2018, 298, 96-114.

28. Su, S.; Zhao, F. The impact of government technology investment policy tools on China's large and medium-sized industrial enterprises' technology investment. Sci. Technol. Manag. Res. 2005, 25, $28-32$.

29. Liu, F.; Sun, Y. Analysis of the effect of China's government investment in science and technology on other investment in science and technology. Res. Dev. Manag. 2007, 19, 100-107.

30. Calantone, R.J.; Cavusgil, S.T.; Zhao, Y. Learning orientation, firm innovation capability, and firm performance. Ind. Mark. Manag. 2002, 31, 515-524. [CrossRef]

31. Drucker, P.F. Post-Capitalist Society; Butterworth Heinemann, Harper Business: Oxford, UK, 1993.

32. Cohen, W.M.; Levinthal, D.A. Absorptive capacity: A new perspective on learning and innovation. Adm. Sci. Q. 1990, 35, 128-152. [CrossRef]

33. Escribano, A.; Fosfuri, A.; Tribó, J.A. Managing external knowledge flows: The moderating role of absorptive capacity. Res. Policy 2009, 38, 96-105. [CrossRef]

34. Murovec, N.; Prodan, I. Absorptive capacity, its determinants, and influence on innovation output: Cross-cultural validation of the structural model. Technovation 2009, 29, 859-872. [CrossRef]

35. Zhao, W. Research on the Relationship between Fiscal Decentralization, Frontier Technology Progress and Technical Efficiency. Manag. World 2008, 7, 34-44, 187. [CrossRef]

36. Zhang, S.; Dai, Y. Heterogeneity, Fiscal Decentralization and Urban Economic Growth—A Research Based on Panel Quantile Regression Model. Financ. Res. 2012, 1, 103-115. 
37. Shen, L. Research on Developmental Finance Model of Science and Technology Infrastructure Construction. Innov. Sci. Technol. 2019, 19, 33-39.

38. Wang, Y.; Pan, X.; Yang, Y. Research on the Spatial Spillover Effect of the Efficiency of Science and Technology Input of Local Governments in China. China Popul. Resour. Environ. 2013, 23, 125-130.

39. Yan, X. The application of public-private partnership (PPP) and the key points of auditing. Audit Res. 2014, 5, 45-51.

40. Zhang, M. Government competition, infrastructure construction and the integration of the Chinese market. J. Guizhou Univ. Financ. Econ. 2012, 6, 21-27.

41. Li, J.; Li, S. Competition among Local Governments in Regional Economic Integration-Based on the Analysis of Incomplete Information Game Model. Urban. Dev. Res. 2009, 16, 97-100.

42. Zhang, G.; Feng, T. Intergovernmental competition, market function expansion policy and China's economic growth. Econ. Syst. Reform 2007, 5, 18-22.

43. Gong, F.; Lu, H. Public expenditure structure, preference matching and fiscal decentralization. Manag. World 2009, 1, 10-21.

44. Hou, X.; Chen, Q.; Zheng, T. Re-examination of the relationship between fiscal decentralization and environmental quality-Based on the perspective of contingency in government preferences. Financ. Trade Res. 2018, 29, 87-98.

45. Zhu, J.; Xu, Z. Fiscal decentralization, inter-regional competition and China's economic fluctuations. Econ. Res. 2018, 1, 21-34.

46. Wen, H.; Lin, B. “Multitasking Competition": A Holistic Explanation of Competitive Incentives among Local Governments in China: Taking the Regional Governance of Guangdong, Hong Kong and Macao as an Example. Jiangsu Soc. Sci. 2020, 1, 75-85.

47. Yehoue, E.B.; Hammami, M.; Ruhashyankiko, J.-F. Determinants of public-private partnerships in infrastructure. No. 2006/099. Int. Monet. Fund 2006. [CrossRef]

48. Chen, S.; Liu, H. Analysis of the influencing factors of PPP model decision-making based on the experience of developing countries. Forum Stat. Inf. 2016, 5, 70-76.

49. Luo, Y.; Wang, F.; Chen, X. How Institutional Quality and International Financial Institutions Affect the Effectiveness of PPP Projects-A Research Based on the Empirical Data of 46 Countries along the "Belt and Road". Financ. Res. 2018, 442, 61-77.

50. Jia, J.; Guo, Q. Tranquility. Fiscal Decentralization, Government Governance Structure and County-level Fiscal Relief. Manag. World 2011, 1, 30-39.

51. Wang, Z.; Guo, X. Government Accounting Information Disclosure, Official Promotion Incentives, and Local Government's Choice of PPP Model. Contemp. Financ. 2018, 407, 125-133.

52. Chen, S. Financial Positioning of Science and Technology Investment: Theoretical Explanation and Empirical Analysis. Contemp. Econ. Res. 2010, 7, 62-67.

53. Guan, Y. The impact of government competition and transfer payments on inter-regional public service inequality. Tech. Econ. 2019, 38, 121-128.

54. Xiao, D.; Zhu, G.; Wang, J. A re-examination of the impact of government investment in science and technology on enterprise R\&D expenditure: An empirical study based on quantile regression. Res. Dev. Manag. 2013, 25, 25-32.

55. Xue, Q. Research on the efficiency of scientific and technological innovation of financial support, government and enterprise input. Sci. Technol. Manag. Res. 2012, 32, 15-19.

56. Zhang, J.; Gao, Y.; Fu, Y.; Zhang, H. Why does China have good infrastructure? Econ. Res. 2007, 3, 4-19.

57. Zhao, D.; Liu, L. The performance of China's science and technology investment from the perspective of externality and endogeneity-Based on the comparison between government and market. Hubei Agric. Sci. 2020, 59, $190-195$.

58. Wang, W.; Zhang, J.; Qin, C. Fiscal Decentralization, Local Government Competition and the Growth Effect of FDI. Manag. World 2007, 3, 13-22, 171. [CrossRef]

59. Ziying, F.; Jun, Z. Fiscal Decentralization, Transfer Payment and Domestic Market Integration. Econ. Res. 2010, 3, 53-64.

60. Fu, Y. Fiscal Decentralization, Government Governance and the Supply of Non-economic Public Goods. Econ. Res. 2010, 8, 4-15. 